\title{
Trawl stress and escapee vulnerability to predation in juvenile walleye pollock: Is there an unobserved bycatch of behaviorally impaired escapees?
}

\author{
Clifford H. Ryer* \\ Fisheries Behavioral Ecology Program, Alaska Fisheries Science Center, National Marine Fisheries Service, NOAA, \\ Hatfield Marine Science Center, Newport, Oregon 97365, USA
}

\begin{abstract}
Recent studies suggest that mortality of undersized fishes escaping through trawl codends may range from 0 to $100 \%$, with mortalities of 10 to $30 \%$ being common. These values may be low, as they do not account for fishes which become behaviorally compromised by their passage through the trawl and ultimately succumb to predators. The goal of this study was to simulate in the laboratory the stressors associated with trawl passage and determine if they degrade the behavioral capabilities of juvenile walleye pollock Theragra chalcogramma to avoid predation. In the first of 2 experiments, groups of Age $1 \mathrm{yr}+$ walleye pollock were subjected to 3 treatments: (1) controls: no stressor; (2) swim/escape: forced swimming for $90 \mathrm{~min}$ at $0.33 \mathrm{~m} \mathrm{~s}^{-1}$ in a towed net, followed by escape through $8 \mathrm{~cm}$ square mesh; (3) swim/crowd/escape: forced swimming followed by 3 min of crowding, followed by escape. To evaluate the effect of these treatments on pollock behavior, a sablefish Anoplopoma fimbria (48 to $53 \mathrm{~cm}$ ) was placed in an observation arena with the group and pollock anti-predator behavior was quantified. Beginning immediately after simulated trawling and for up to $24 \mathrm{~h}$ afterwards, pollock exposed to both trawl-stressor treatments were less likely to avoid the predator than controls, allowing it to approach closer. They were also less able to form a cohesive shoal, and in the case of the swim/crowd/escape treatment, swam more slowly than control fish. To determine if trawl-stressed fish are more vulnerable to predation, in a second experiment I mixed control and swim/crowd/escape pollock together and then subjected them to predation by a 48 to $60 \mathrm{~cm}$ lingcod Ophiodon elongatus, observing the behavior and enumerating the number of pollock consumed in each treatment. Lingcod concentrated attacks upon solitary individuals or those straggling behind the shoal, were more likely to lunge at pollock that did not move away when approached, and were more successful the closer the pollock at lunge initiation. As a result, trawlstressed pollock were consumed in greater numbers than controls. On the basis of these results, it is reasonable to expect that juvenile walleye pollock passing through trawls suffer behavioral deficits, subjecting them to elevated predation risk. If this is a generic effect, these results suggest that there may be a significant bycatch associated with many commercial trawl fisheries which is generally unrecognized, unmeasured, and unaccounted for in current stock-assessment models.
\end{abstract}

KEY WORDS: Bycatch · Predation · Stress · Trawl $\cdot$ Walleye Pollock $\cdot$ Behavior

\section{INTRODUCTION}

The bycatch of undersized and nontarget fishes by trawl gear is increasingly perceived by fisheries man-

*E-mail: cliff.ryer@hmsc.orst.edu agers, ecologists, conservationists and society at large, as an undesirable consequence of commercial fishing (Alverson \& Hughes 1996, Agardy 2000). In its broadest sense, the bycatch includes both an observed component (i.e. undersized fishes and nontarget species that arrive on deck and are either kept or discarded) and an unobserved component, i.e. fishes that never 
appear on deck, but die after encountering and escaping the fishing gear (Crowder \& Murawski 1998). To reduce the observed bycatch, many trawl fisheries have adopted larger mesh sizes, allowing smaller fishes to escape from the codend. While larger meshes, square mesh, escape panels and bycatch-reductiondevices can effectively reduce the observed bycatch (Tumilty et al. 1998), if fishes escaping trawls do not survive, they simply become part of the unobserved bycatch.

Mortality of fishes that pass through trawls is problematic for scientists and managers because it is unmeasured and infrequently incorporated into stockassessment calculations (Chopin \& Arimoto 1995, Alverson \& Hughes 1996, Crowder \& Murawski 1998). However, recent studies utilizing cages to surround the trawl codend and retain escapees (Lehtonen et al. 1998) demonstrate that mortality can be extensive and vary greatly between species. For example, the Baltic cod Gadus morhua displayed a 10 to $14 \mathrm{~d}$ mortality of only $1 \%$ after passing through a bottom trawl equipped with $95 \mathrm{~mm}$ square-mesh escape panels (Suuronen et al. 1996a), while 2 other gadids, the haddock Melanogrammus aeglifinus and the whiting Merlangius merlangus, displayed $60 \mathrm{~d}$ mortalities of 11 to $52 \%$ and 14 to $48 \%$, respectively, after escaping through various codend meshes ranging from 70 to $110 \mathrm{~mm}$ (Sangster et al. 1996). The herring Clupea harengus had $7 \mathrm{~d}$ mortalities ranging from $72 \%$ for small fish $(<12 \mathrm{~cm})$ to $30 \%$ for larger fish $(12$ to $17 \mathrm{~cm})$ (26 and $36 \mathrm{~mm}$ stretch-mesh codends: Suuronen et al. 1996b), and the vendace Coregonus albula $50 \%$ mortality (24 mm square-mesh codend: Suuronen et al. 1995). However, these mortality estimates are probably low, as they ignore sublethal effects upon fish behavior that may influence survival. In these studies, the cage which retains escapees is detached from the trawl and either rests on the seafloor or is suspended in the water column, with fish survival monitored over time. While holding fishes captive for monitoring, the cage also has the unintended consequence of protecting them from some of the rigors of their environment, most notably predators.

Increased vulnerability to predation may be an important yet unobserved source of mortality for fishes escaping trawl gear. The stressors involved and their influence upon fishes probably varies with fish size and species, type of trawl gear, tow speed and duration, catch size, and oceanographic conditions such as temperature and illumination. Yet, diver and video observations suggest a common scenario. Fishes encountering trawls swim so as to maintain their position ahead of or within the gear (Wardle 1983, Suuronen et al. 1997b). As they tire, they gradually fall farther back towards the codend. Severe exhaustion may result in decreased muscle and liver glycogen levels (Suuronen et al.1996b, Turunen et al. 1996) as well as osmotic imbalance (Turunen et al. 1996). Also, the fishes may periodically strike other fishes, debris and the meshes, causing abrasions and scale loss (Sangster et al. 1996, Suuronen et al. 1996a,b, Broadhurst et al. 1997). As a fish approaches the catch ball at the rear of the codend, it may be further crowded by other fish and debris. Lastly, to escape, a fish must swim through an opening in the mesh, which may also result in abrasion and scale damage. These more obvious physical injuries and exhaustion may induce a subsequent cascade of biochemical and physiological changes that can directly modify innate and/or learned behavioral responses to environmental stimuli (reviewed by Schreck et al. 1997). While short-term modification of feeding and aggressive motivation may have little effect upon survival, even a brief hiatus in predator detection, avoidance, schooling and shelter seeking could have profound implications for survival.

I conducted experiments on the effect of simulated trawl passage upon the anti-predator behavior of juvenile walleye pollock Theragra chalcogramma. This species supports a large commercial fishery in Alaskan waters, with more than $10^{6} \mathrm{t}$ taken in 2000 (NOAA; see www.fakr.noaa.gov/2000/bsa00b. txt). This mid-water fishery targets predominantly $3 \mathrm{yr}$ and older fish (>30 cm total length). Although younger fish tend to occur at shallower depths than the older fish (McKelvey 1996), their similar distribution suggests that substantial numbers may pass through codends unnoticed. Indeed, many fishers have switched to larger and/or square mesh codends to reduce their catch of undersized/unmarketable fish. Yet, mortality of undersized walleye pollock exiting codend intermediates through $93 \mathrm{~mm}$ square mesh escape panels may be 36 to $68 \%$ (Erickson et al. 1999). Therefore, a low retention of fish $<20 \mathrm{~cm}$ (Fritz 1996) affords little assurance that they are not being impacted. Similarly, various other Alaskan trawl fisheries for both flatfishes and roundfishes probably encounter juvenile walleye pollock.

I present the results of 2 experiments designed to address the possible effects of trawl passage upon juvenile walleye pollock. In the first, I sought to determine what aspects of behavior might be impaired. I exposed pollock to stressors designed to simulated passage through a trawl and then observed their behavior in the presence of a threatening, but nonlethal predator. In the second, I sought to determine whether trawl-induced stress might increase escapee vulnerability to predation. Fish having undergone a simulated trawl passage were combined with control fish and then exposed to a lethal predator, allowing comparison of their relative mortality. 


\section{MATERIALS AND METHODS}

Fish collection and maintenance. Juvenile walleye pollock Theragra chalcogramma were collected from Puget Sound, Port Townsend, Washington, USA, during June 1999 and transported back to the laboratory in Newport, Oregan, USA. Two additional fish species were collected for use as predators: the sablefish Anoplopoma fimbria and the lingcod Ophiodon elongatus. Sablefish were captured as juveniles during April 1998, while lingcod were captured as adults during April and May 1999, both off Newport. Each species of fish progressed through a range of holding tank sizes as they grew, but during the last several months prior to experimentation walleye pollock were kept in 37001 circular tanks (2.3 m diameter, $0.9 \mathrm{~m}$ depth), while sablefish and lingcod were kept in $25400 \mathrm{l}$ circular tanks (3 $\mathrm{m}$ diameter, $0.9 \mathrm{~m}$ depth). Holding tanks were provided with a continuous flow of seawater (salinity range 28 to $33 \%$, temperature range 9 to $11^{\circ} \mathrm{C}$. Walleye pollock and sablefish were fed pelletized food daily for the first $6 \mathrm{mo}$, after which the walleye pollock continued on pellets thrice weekly and the sablefish received thawed squid Loligo sp. twice weekly. Rations for pollock and sablefish were periodically adjusted to promote growth. Lingcod were fed once weekly on a maintenance ration of assorted live or thawed baitfish.

Nonlethal predation experiment. The behavioral response of juvenile walleye pollock to a nonlethal but threatening sablefish predator was quantified after sequential exposure to stressors simulating those associated with entrainment and escape from a trawl. The experiment incorporated 3 treatments: swim/crowd/ escape, swim/escape and control. Six replicates of each treatment were conducted in 6 replicate 254001 circular arenas (3 m diameter, $0.9 \mathrm{~m}$ depth) monitored by overhead video cameras. Arenas received a continuous flow of 9 to $11^{\circ} \mathrm{C}$ seawater and were illuminated by fluorescent lighting ( $4 \mu \mathrm{mol}$ photons $\mathrm{m}^{-2} \mathrm{~s}^{-1}$ at the water surface). For controls, groups of 6 walleye pollock were placed into the arenas $18 \mathrm{~h}$ prior to experimental procedures, while for the 2 trawl-stress treatments, 7 pollock were placed in arenas, the extra fish was included to allow for occasional deaths. The swim/crowd/escape trials simulated sustained swimming, followed by crowding prior to escape through codend meshes. Walleye pollock were dipnetted from their arenas using a fine nylon-meshed net and transferred by bucket to a net-towing apparatus (see Olla et al. 1997 for complete description). Briefly, the apparatus consists of a $16000 \mathrm{l}$ circular tank (4.5 m diameter, $1.0 \mathrm{~m}$ depth) in which nets are towed in a circular path around the tank's perimeter. The tow net consisted of a rigid plastic cylinder (30 cm diameter, $35 \mathrm{~cm}$ length) attached to a $60 \mathrm{~cm}$ sleeve of $3.2 \mathrm{~cm}$ mesh (diagonal stretch measured) knotted near its end (Fig. 1A). The other end of the cylinder was fitted with a removable cover made from a rigid plastic ring covered with $3.2 \mathrm{~cm}$ mesh. Pollock were gently poured from the bucket into the submerged tow net, the cover was secured, and the net was towed around the tank with the water entering through the cover at the front of the cylinder and exiting through the net sleeve to the rear. While towed, the fish typically maintained position in the rear of the cylinder and/or in the front of the mesh sleeve. In commercial trawls towed at 1.0 to $2.6 \mathrm{~m} \mathrm{~s}^{-1}$ ( 2 to 5 knots), fishes probably experience codend water velocities of 0.3 to $0.8 \mathrm{~m} \mathrm{~s}^{-1}$, assuming water velocity in the codend is reduced to $30 \%$ of the tow speed (Thiele et al. 1997). In preliminary trials it became apparent that, while many fish would swim indefinitely at the higher of these speeds, other fish would not. This may have been related to the confined nature of the tow apparatus: in a larger tow net Olla et al. (1997) found that walleye pollock of comparable size were able to swim for over $3 \mathrm{~h}$ at $0.7 \mathrm{~m} \mathrm{~s}^{-1}$. While fish that tire or fail to swim in a trawl can fall back and potentially pass through the mesh of the codend, in my apparatus these fish became pinned against the mesh and typically died if they remained there for more than $15 \mathrm{~min}$, as judged by cessation of opercular movement. Therefore, I adopted a tow speed that forced fish to swim at $0.33 \mathrm{~m} \mathrm{~s}^{-1}$, a pace at which most fish would swim. Nonetheless, even at this speed, in some groups 1 fish, or less frequently 2 , still failed to swim, thus the addition of an extra fish in trawl-stress groups. How long individual fish swim in trawls is unknown, so I arbitrarily chose a swim duration of $90 \mathrm{~min}$. At the end of this 90 min the cover of the tow net was detached and any

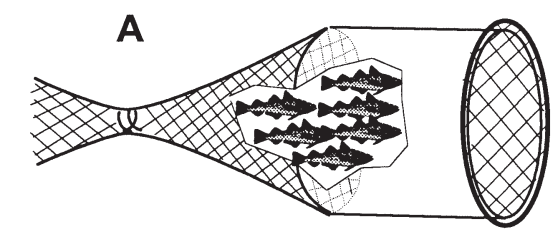

B
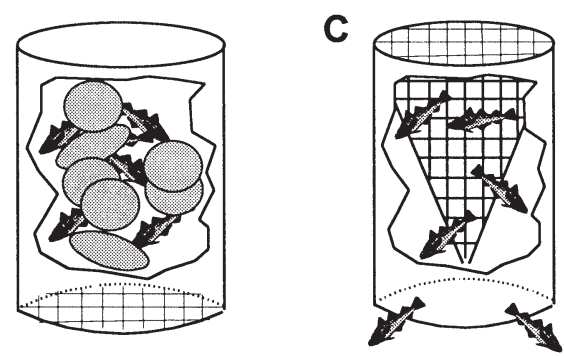

Fig. 1. (A) Forced-swimming apparatus; (B) crowding apparatus; (C) codend escape apparatus 
fish that had failed to swim were removed: these were always dead. If there were no non-swimmers, a single fish was haphazardly removed. The remaining fish were gently poured into the crowding apparatus (Fig. 1B) where they were subjected to a $3 \mathrm{~min}$ period of 'crowding', while being transferred back to their arena. This apparatus consisted of a 191 bucket with a soft nylon $3 \mathrm{~mm}$-mesh bottom situated in a larger container filled with $10^{\circ} \mathrm{C}$ seawater. As soon as the fish were placed into the bucket, 24 balloons, filled with water to a diameter of 10 to $13 \mathrm{~cm}$, were added by hand. Then, a second bucket with a mesh bottom was nested into the first and weighted down so that the fish, while still in water, were confined to the spaces between the spherical balloons. Again, it is unknown how long fish will endure crowding at the front of an accumulating catch ball before they effect their escape, so I arbitrarily chose to subject the fish to $3 \mathrm{~min}$ of crowding, after which the balloons were removed and the fish were gently poured from the bucket into the codend escape cone (Fig. 1c), which was suspended in the arena. The escape cone was made of knotless square mesh suspended in a rigid plastic cylinder (40 cm diameter by $54 \mathrm{~cm}$; Fig. 1C). The mesh, made of $9 \mathrm{~mm}$ diameter poly-twine, was held in square configuration, with individual openings measuring $4.3 \mathrm{~cm}$ along the side $(6.0 \mathrm{~cm}$ diagonal $)$. This mesh is commonly utilized in the Alaskan mid-water trawl fishery as a means of reducing the landing of undersized fish. The cylinder and cone were gently agitated in the water until all fish had 'escaped' through the mesh into the arena. In all cases, it took less than $30 \mathrm{~s}$ for all the fish to make their escape.

The swim/escape trials simulated sustained swimming followed by immediate escape. These trials were conducted exactly like the swim/crowd/escape trials, except the walleye pollock were transferred in a bucket from the swimming apparatus to the codend escape cone, without the crowding sequence. For control trials the juveniles remained in the arena. Six replicate trials of each treatment were conducted. During each of 2 successive weeks, 3 swim/crowd/escape trials and 3 control trials were conducted concurrently. In the week that followed, all 6 swim/escape trials were conducted concurrently. In each of 2 swim/ escape trials and 2 swim/crowd/escape trials, a single fish failed to swim, became pinned against the mesh and died. In 2 swim/escape trials and 1 swim/crowd/ escape trial, 2 fish died in this manner. Therefore, while each of the controls utilized 6 fish, 2 of the swim/ escape and 1 of the swim/crowd/escape trial groups contained only 5 fish during the subsequent observations of behavior.

Juvenile walleye pollock faced 4 predator challenges, the first as they escaped into the arena, the sec- ond $2 \mathrm{~h}$ later, then 1 and 3 d later. For each challenge a single sablefish (48 to $53 \mathrm{~cm}$ total length) was dipnetted into the arena and then dipnetted back out 20 min later. In their holding tanks, the sablefish were kept at $6^{\circ} \mathrm{C}$, approximately $4^{\circ} \mathrm{C}$ below the temperature in the arenas. As a result of the temperature change they experienced upon transfer into the arenas the sablefish made no overt attempts to consume the juvenile pollock, although they swam continuously around the perimeter of the arena until removed. In 1 instance, a sablefish settled to the arena bottom and remained motionless for $1 \mathrm{~min}$ before it commenced swimming.

One, 2, 3 and $6 \mathrm{~d}$ after simulated net stresses, each group of fish was given pelletized food over a $3 \mathrm{~min}$ period and the number of fish in each group which consumed at least 1 pellet was recorded. Several hours after the last feeding (day 6) the fish were removed from the arena, weighed, measured, and then transferred to $3700 \mathrm{l}$ holding tanks $(2.3 \mathrm{~m}$ diameter, $0.9 \mathrm{~m}$ depth), where they were segregated by experimental treatment and monitored daily for mortality over $4 \mathrm{wk}$. Fish total length ranged from 171 to $216 \mathrm{~mm}$, with no differences in mean length or weight between treatments: mean length (SE) = control 192.6 (1.8), swim/ escape 194.0 (1.8), swim/crowd/escape 193.7 (1.4), $F=$ $0.19, \mathrm{df}=2, \mathrm{p}=0.824$; mean weight $(\mathrm{SE})=$ control $54.5 \mathrm{~g}$ (1.6), swim/escape 57.1 (1.9), swim/crowd/ escape 56.4 (1.4), $F=0.67$, df $=2, \mathrm{p}=0.516$.

From videotapes, for each predator challenge $(0,2$, 24 and $72 \mathrm{~h}$ ), I digitized the swim path of each walleye pollock in each group, as well as the predator, for a 2 min period. This period began 1 min after the predator was introduced. I calculated the average swimming speed for both predator and prey over the $2 \mathrm{~min}$ period. This data set also provided a time series of 2dimensional spatial coordinates describing the position of each fish, relative to the others, at $0.5 \mathrm{~s}$ intervals. I calculated the distance between each walleye pollock and its nearest neighbor (Clark \& Evans 1954) and the distance between each walleye pollock and the predator for each interval. From the distance-to-predator data I determined the closest-approach distance, i.e. the smallest distance between each pollock and the predator during the 2 min period. Nearest-neighbor and distance-to-predator data were averaged over the 2 min period for each fish and then averaged by group. Swim speed and closest-approach distance were averaged for each group. Characterizing 3-dimensional spatial relationships using only 2-dimensional data has obvious shortcomings; however, both walleye pollock and sablefish tended to swim predominantly near the water surface, so it is my impression that the distance measurements I derived were not greatly affected. Furthermore, there were no obvious differences in fish vertical distribution between treatments. Therefore, I 
assume any errors introduced through 2-dimensional measures were comparable across treatments. Data were homoscedastic, as indicated by Bartlett's test of equal variance (Sokal \& Rohlf 1969), and were analyzed by repeated-measures ANOVA (Hicks 1982). Where statistical effects were significant $(\mathrm{p}<0.05), a$ posteriori multiple comparisons were conducted utilizing Ryan's Q-test (Day \& Quinn 1989).

Lethal predation experiment. Equal numbers of control and swim/crowd/escape walleye pollock were mixed together and then exposed to predation by a single lingcod to compare their relative vulnerability to predation. Four arenas were fitted with opaque plastic vertical partitions which divided each arena in half. The partitions could be raised completely out of the arenas using wires running through pulleys attached to the ceiling. In all respects, including color, position of inflows and drains, water temperature and lighting, these partitioned arenas were identical. Eighteen hours prior to initiation of experimental procedures, groups of 5 walleye pollock were measured for total length and then had either the upper or lower tip of their caudal fin clipped to allow for identification of control versus stress groups. Only a small amount of fin was removed, and this was unlikely to affect fish performance; in addition, both trawl-stress and control fish received clips, which were alternated for each trial, i.e. controls that received upper caudal clips in one trial received lower clips in the next trial, and vice versa. With the partitions down, control fish were placed into one half of an arena, while fish to be stressed were placed in one half of a second arena. In each case, a single lingcod (48 to $60 \mathrm{~cm}$ ) was placed on the opposite side of the partition. The lingcod had not been fed for 10 to $14 \mathrm{~d}$. Water entered the arena through an inflow pipe on the predator side of the arena and exited via an overflow fitting on the prey side. The partition had numerous $1.2 \mathrm{~cm}$ holes that allowed water movement from one side to the other.

The next morning, the stress group was dipnetted from their arena and put through the same swim/ crowd/escape procedure described for the nonlethal experiment. Rather than being put back into their arena, the stress fish were instead allowed to 'escape' into the arena with the control fish. As a result, the arena now contained 5 stressed and 5 control fish on one side of the moveable partition, with the predator on the other side. Immediately after the stress fish were released, the lights in the room were turned off for approximately $30 \mathrm{~s}$ and the partition was raised allowing the predator to mingle with the control and stressed walleye pollock, then the lights were turned back on. The trials were continued for $30 \mathrm{~min}$ or until the lingcod had consumed 5 pollock, whichever came first. The walleye pollock were then dipnetted out of the arena and enumerated by fin clip to determine the number of control and trawl-stressed fish consumed. Seven replicate trials were conducted. Total fish length did not differ between treatments within any of the paired control/stress trials, or in the experiment as a whole (student's $t$-tests, $\mathrm{p}>0.05$ for each). Mortality data were analyzed using a 1-tailed sign test (Sokal \& Rohlf 1969).

Overhead video recordings were made of each trial, and observations of the behavior of both pollock and lingcod recorded. Lingcod initially rushed around the arena in pursuit of the pollock until they made their first capture: no behavioral data were recorded during this period. After taking their first pollock, the lingcod all adopted a stalking strategy, whereby the lingcod would slowly approach a pollock; some stalks were abandoned, while others culminated in a lunge at the pollock. For stalks that culminated in a lunge, the distance between predator and prey at lunge initiation was recorded, while for stalks that were abandoned the closest approach between predator and prey was recorded. To determine whether the distance between the lingcod and its prey influenced whether or not a lunge was initiated, mean lunge and closest-approach distances were calculated for each trial and the resultant data set analyzed by a paired $t$-test (Sokal \& Rohlf 1969). Similar calculations were made to determine whether successful lunges (i.e. the pollock was at least temporarily captured) were launched from a shorter distance than unsuccessful lunges.

\section{RESULTS}

\section{Nonlethal predation experiment}

Simulated trawl passage compromised juvenile walleye pollock anti-predator behavior in several tangible ways, with the magnitude of degradation greatest for fish exposed to the swim/crowd/escape treatment. First, these fish were lethargic, that is they swam slower than control fish (Fig. 2, Table 1), with the effect most acute during the first $2 \mathrm{~h}$ post-trawl, but still significant $24 \mathrm{~h}$ afterwards. During the first $2 \mathrm{~h}$ posttrawl, swim/crowd/escape fish often appeared distressed, swimming at an upward angle relative to the horizontal and repeatedly poking their snouts out of the water, indicating disorientation and/or swim bladder dysfunction. While not obviously distressed, swim/ escape fish also tended to swim slower than controls, although this was only statistically demonstrable $24 \mathrm{~h}$ post-trawl. Second, both swim/crowd/escape and swim/escape fish were less responsive than control fish to predator movements during the first $2 \mathrm{~h}$ post-trawl. As the predator swam about the arena, the trawl- 
passage fish were closer to the predator than the control fish (Fig. 3, Table 1). Although the predator never made overt attempts to capture walleye pollock, the control fish tended to stay on the opposite side of the tank, while trawl-passage fish often appeared unaware of the predator's approach, in many instances allowing the predator to pass within several centimeters. This was apparent from closest-approach dis-

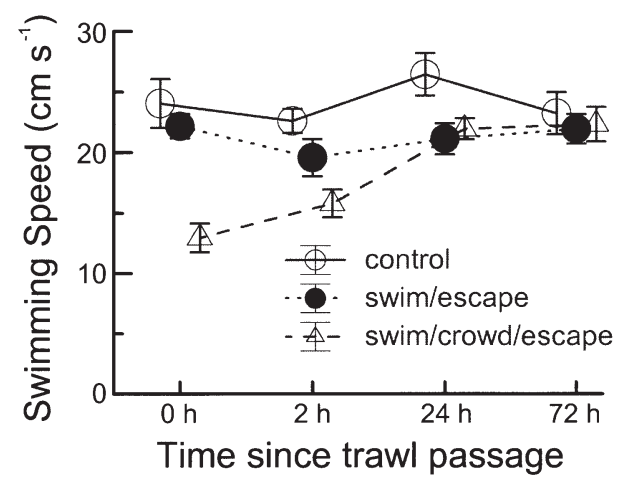

Fig. 2. Theragra chalcogramma. Mean swimming speed $( \pm \mathrm{SE})$ of juvenile walleye pollock exposed to a sablefish predator (Anoplopoma fimbria) at times ranging from 0 to $72 \mathrm{~h}$ after simulated trawl passage

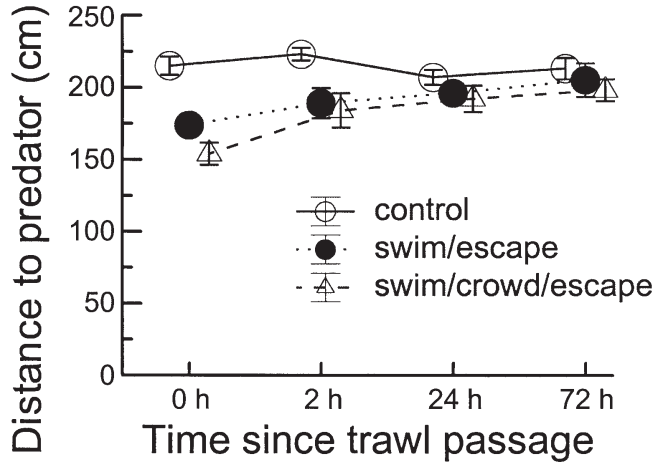

Fig. 3. Theragra chalcogramma. Mean distance $( \pm \mathrm{SE})$ between juvenile walleye pollock and a sablefish predator at times ranging from 0 to $72 \mathrm{~h}$ after simulated trawl passage

Table 1. Theragra chalcogramma. Swim speed, distance from predator, closest approach distance and nearest-neighbor-distance analysis $0,2,24$ and $72 \mathrm{~h}$ after simulated trawl passage. Min-dist-pred: minimum distance from predator; C: controls; S/E: swim/escape; S/C/E: swim/crowd/escape. Homogeneous subgroups of means are underlined

\begin{tabular}{|c|c|c|c|c|c|}
\hline & df & SS & MS & $F$ & $\mathrm{p}$ \\
\hline \multicolumn{6}{|l|}{ Swim speed ANOVA } \\
\hline Treatment & 2 & 40672.9 & 20336.5 & 10.15 & 0.002 \\
\hline Treatment $\times$ Replicate & 5 & 30050.2 & 2003.35 & & \\
\hline Time & 3 & 20321.3 & 6773.76 & 7.73 & 0.000 \\
\hline Treatment $\times$ Time & 6 & 26013.9 & 4335.65 & 4.95 & 0.001 \\
\hline Treatment $\times$ Time $\times$ Replicate & 45 & 39444.3 & 876.54 & & \\
\hline \multicolumn{6}{|c|}{ 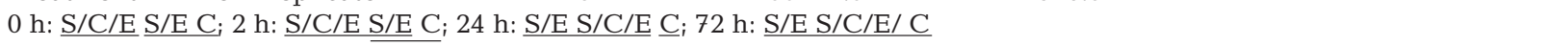 } \\
\hline \multicolumn{6}{|l|}{ Distance-predator ANOVA } \\
\hline Treatment & 2 & 1372410 & 686205 & 11.16 & 0.001 \\
\hline Treatment $\times$ Replicate & 15 & 922712 & 61514.1 & & \\
\hline Time & 3 & 597172 & 199057 & 6.32 & 0.001 \\
\hline Treatment $\times$ Time & 6 & 496151 & 82691.9 & 2.63 & 0.029 \\
\hline Treatment $\times$ Time $\times$ Replicate & 45 & 1416785 & 31484.1 & & \\
\hline \multicolumn{6}{|c|}{ 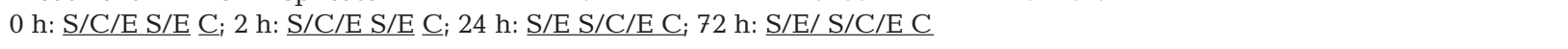 } \\
\hline \multicolumn{6}{|l|}{ Min-dist-pred ANOVA } \\
\hline Treatment & 2 & 1459191 & 729596 & 6.23 & 0.011 \\
\hline Treatment $\times$ Replicate & 15 & 1755917 & 117061 & & \\
\hline Time & 3 & 819447 & 273149 & 2.97 & 0.042 \\
\hline Treatment $\times$ Time & 6 & 448790 & 74798.3 & 0.81 & 0.566 \\
\hline Treat $\times$ Time $\times$ Replicate & 45 & 4144213 & 92093.6 & & \\
\hline \multicolumn{6}{|l|}{ Times combined: S/C/E S/E C } \\
\hline \multicolumn{6}{|l|}{ Nearest-neighbor ANOVA } \\
\hline Treatment & 2 & 288109 & 144055 & 8.19 & 0.004 \\
\hline Treatment $\times$ Replicate & 15 & 263873 & 17591.6 & & \\
\hline Time & 3 & 105158 & 35052.8 & 4.01 & 0.013 \\
\hline Treatment $\times$ Time & 6 & 222962 & 37160.4 & 4.25 & 0.002 \\
\hline Treatment $\times$ Time $\times$ Replicate & 45 & 39444.3 & 876.54 & & \\
\hline 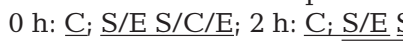 & $\mathrm{C}_{i} \underline{\mathrm{S} /}$ & : $\underline{\mathrm{S} / \mathrm{E} C \mathrm{C} /}$ & & & \\
\hline
\end{tabular}




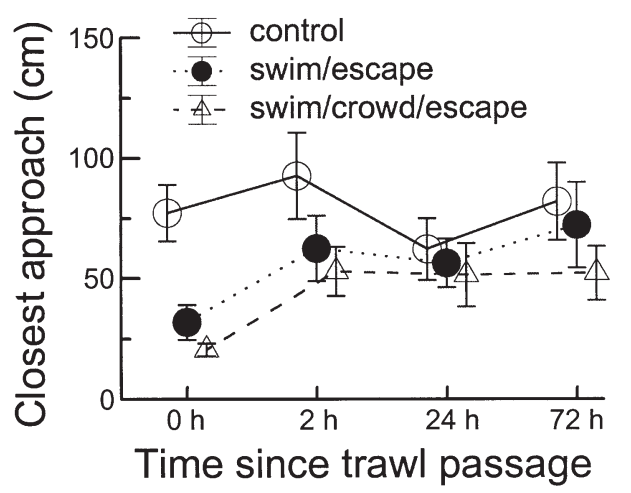

Fig. 4. Theragra chalcogramma. Mean closest approach $( \pm \mathrm{SE})$ between juvenile walleye pollock and a sablefish predator at times ranging from 0 to $72 \mathrm{~h}$ after simulated trawl passage

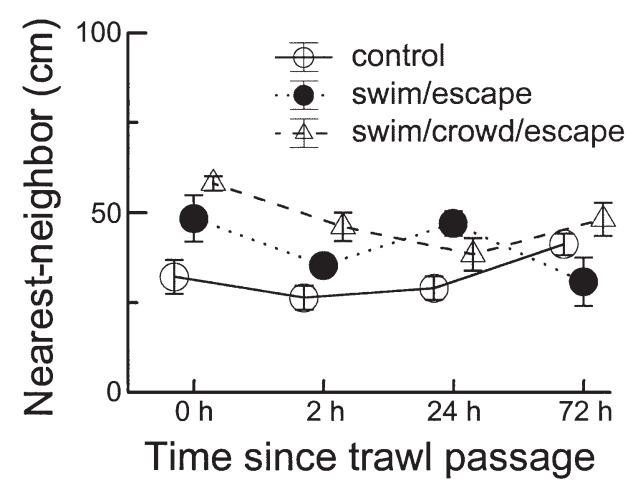

Fig. 5. Theragra chalcogramma. Mean nearest-neighbor distances $( \pm$ SE) for juvenile walleye pollock exposed to a sablefish predator at times ranging from 0 to $72 \mathrm{~h}$ after simulated trawl passage

tances, which were approximately one third of those measured for control fish (Fig. 4). Although ANOVA indicated that closest-approach distances differed throughout the $72 \mathrm{~h}$ experiment (i.e. non-significant interaction in Table 1), from Fig. 4, I would infer that this effect was prominent for only the first post-trawl hour or so. Finally, just as trawl-passage fish were closer to the predator, so too were they less capable of shoaling. Statistical analysis (Table 1) and examination of Fig. 5 indicate that up to $24 \mathrm{~h}$ post-trawl, the trawlpassage fish maintained greater nearest-neighbor distances than control fish. Trawl-passage fish often splintered into smaller groups or swam solitarily, whereas control fish appeared more likely to maintain a single cohesive shoal.

Differences in juvenile walleye pollock behavior were not a result of variation in predator behavior. Predator swimming speed was relatively constant at approximately $30 \mathrm{~cm} \mathrm{~s}^{-1}$ and did not differ between treatments or over time (treatment: $F=2.21, \mathrm{df}=2, \mathrm{p}=$
0.116 ; time: $F=1.63, \mathrm{df}=3, \mathrm{p}=0.190$; interaction: $F=$ $0.92, \mathrm{df}=6, \mathrm{p}=0.489$ ). In all trials, sablefish predators predominantly swam around the perimeter of the arenas, making only occasional forays across interiors.

Trawl-passage fish appeared to have recovered $72 \mathrm{~h}$ post-trawl, as I detected no differences between any of the treatment groups with respect to swim speed, distance from the predator or nearest-neighbor distances. Because fish remained in the arenas for $6 \mathrm{~d}$ after trawlpassage, I could not quantify scale loss or skin damage attributable to treatments. However, arena-side observations revealed a higher frequency of snout bruising among swim/crowd/escape fish $(37 \%, \mathrm{SE}=9)$ compared to swim/escape $(3 \%, \mathrm{SE}=3)$ and control $(0 \%$, Kruskal-Wallis $\mathrm{p}<0.001)$ fish. On the first day after trawl passage, more of the control and swim/crowd/ escape fish fed than did fish from the swim/escape treatment (control $94 \%, \mathrm{SE}=4$; swim/crowd/escape $91 \%, \mathrm{SE}=4$; swim/escape $65 \%, \mathrm{SE}=4 ; F=17.52$, $\mathrm{df}=2, \mathrm{p}<0.001)$. On the $2 \mathrm{nd}, 3 \mathrm{rd}$ and 6 th days there were no significant differences in feeding, with more than $83 \%$ (5 out of 6 fish) feeding in each treatment. There were no mortalities among juvenile walleye pollock, regardless of treatment, during the $6 \mathrm{~d}$ posttrawl in the arenas, or during the subsequent 4 wk in holding tanks.

\section{Lethal predation experiment}

As soon as the partition was raised and lights were turned on, lingcod charged the juvenile pollock, taking their first prey in an average of $18 \mathrm{~s}(\mathrm{SD}=19)$. Subsequently, the pollock were more wary and the lingcod adopted a stalking strategy entailing a slow approach towards an individual or group of pollock, sometimes culminating in a lunge. Lingcod appeared to stalk primarily those pollock which were not shoaling or were straggling behind a shoal. How close the lingcod was able to get to the pollock during the stalk determined whether a lunge was initiated. When the pollock moved away as the lingcod approached, the stalk was abandoned and the lingcod settled back to the bottom (38\% of stalks). For these abandoned stalks, the mean closest approach between lingcod and pollock was $44.2 \mathrm{~cm}(\mathrm{SE}=3.5)$. However, when the stalk resulted in a lunge ( $62 \%$ of stalks), the mean distance between lingcod and pollock at lunge initiation was only $30.4 \mathrm{~cm}(\mathrm{SE}=4.4$, paired $t=-2.55, \mathrm{df}=6, \mathrm{p}=0.043)$. Fifty-one percent of lunges culminated in success (i.e. pollock were at least temporarily captured) and were initiated from a closer mean distance than were unsuccessful lunges (successful $=22.6 \mathrm{~cm}, \mathrm{SE}=3.4$; unsuccessful $=38.5 \mathrm{~cm}, \mathrm{SE} 6.6 ;$ paired $t=3.94, \mathrm{df}=6, \mathrm{p}=$ $0.008)$. 


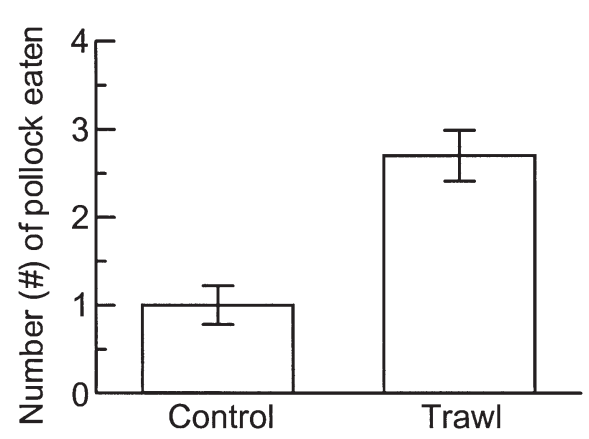

Fig. 6. Theragra chalcogramma. Mean number $( \pm \mathrm{SE})$ of control and trawl-stressed walleye pollock consumed during 30 min encounters with a lingcod predator (Ophiodon elongatus). Trawl-stressed fish pollock were subjected to the swim/ crowd/escape treatment

Trawl-stressed pollock were more vulnerable to predation than control fish (Fig. 6). In 6 of 7 trials, lingcod consumed more stressed than control pollock, while in 1 trial equal numbers of stressed and control fish were consumed (1-tailed sign test, $\mathrm{p}=0.016)$.

\section{DISCUSSION}

In this study I subjected juvenile walleye pollock to 2 treatments simulating passage through a trawl. In both, the pollock resumed feeding several days afterwards and experienced no mortality over $5 \mathrm{wk}$. Therefore, I conclude that the stressors involved were, in and of themselves, nonlethal. However, both trawl-passage treatments produced measurable deficits in antipredator behavior. Pollock from both treatments formed less cohesive shoals than controls, allowed the predator to make closer approaches, and in the case of the swim/crowd/escape treatment they were initially disoriented and more lethargic than control fish. Further, when pollock subjected to the higher of the 2 trawlstress regimes were exposed to predation along with unstressed pollock, the trawl-stress fish experienced greater predation mortality. Taken together, these results indicate that juvenile walleye pollock passing through trawl codends may have their behavioral capabilities degraded and suffer elevated predation in the subsequent hours and/or days.

Were the stressors applied in this study reasonable and relevant compared to those experienced during actual trawling? Diver and video observations (Suuronen et al. 1996a,b, Olla et al. 2000) would suggest that the 'swim-crowd-escape' scenario captures the essence of what fish experience when passing through a codend. However, the magnitude of each stressor was, by design, scaled down to minimize mortality. Minimizing mortality was essential, since behavioral im- pairment in fish already destined to die as a direct consequence of stress (as opposed to indirect behaviorally mediated predation) is of little consequence from either an ecological or population dynamics perspective. Rather, it is the behavior of individuals that would otherwise recover that is of interest. The stressors I utilized differed from real trawling in the following respects: (1) the $0.33 \mathrm{~m} \mathrm{~s}^{-1}$ swim speed was at the low end of the 0.3 to $0.8 \mathrm{~m} \mathrm{~s}^{-1}$ that walleye pollock probably experience in codends; (2) the walleye pollock were not exhausted, as they can swim at over twice this speed for over $3 \mathrm{~h}$ (Olla et al. 1997); (3) the crowding procedure did not subject the fish to the more extreme physical damage from collisions with debris, spines and calcified fin-rays, etc., that can accompany crowding in bottom trawls (Suuronen et al. 1997a,b); (4) during simulated codend escape, the pollock were not subjected to the turbulent shear forces experienced by fish escaping from actual codends (pers. obs.). Therefore, the entire stressor sequence utilized in this study probably simulated the minimum level of what walleye pollock and other fish experience in commercial gears (Suuronen et al. 1995, 1996b, Sangster et al. 1996). However, walleye pollock still experienced significant behavior impairment from these nonlethal stressors. Presumably actual trawl passage, which produces significant mortality in walleye pollock (Erickson et al. 1999), will also degrade behavior in the surviving escapees. Taken together, these factors suggest that the methodology utilized in this study constitutes a relatively conservative test of the hypothesis that trawl passage degrades walleye pollock behavior.

A variety of sublethal stressors, not unlike those experienced by trawl escapees, are known to compromise behavior and render fish more vulnerable to predation (see reviews by Mesa et al. 1994, Olla et al. 1997). Chinook salmon Oncorhynchus tshawytscha and coho salmon $O$. kisutch smolts stressed by handling (held out of water in a dipnet for 30 to $60 \mathrm{~s}$ ) and then mixed with an equal number of control fish were consumed in greater numbers than controls by the lingcod Ophiodon elongatus (Olla \& Davis 1989, 1992, Olla et al. 1995). Similarly, chinook salmon smolts stressed by either handling (simulating hatchery release) or agitation (simulating dam passage) were lethargic and more vulnerable than controls to predation by pike-minnows Ptychocheilus oregonensis (Mesa 1994). A host of other stressors including temperature shock (Coutant 1973, Webb \& Zhang 1994), starvation (Herting \& Witt 1967, Rice et al. 1987), disease (Mesa et al. 1998) and toxicants (Brown et al. 1985, Little et al. 1990) have similar effects upon prey vulnerability. Therefore, rather than being unique, trawl passage would appear to be 1 more addition to a growing list of stressors that may result in behavioral impairment and increased vulnerability to predation. 
Whether trawl stress resulted in a degraded ability to detect predators, or a failure to respond appropriately, it is clear that juvenile walleye pollock demonstrated reduced avoidance capacity. In the nonlethal experiment trawl-stressed pollock allowed the predator to get closer than did controls, and in the swim/crowd/ escape treatment the disorientation and lethargy of some individuals was so severe that they appeared oblivious to predator presence. This was probably partly responsible for the greater vulnerability of trawl-stressed pollock in the lethal predation experiment, where predators primarily lunged at those pollock they could get close to and were more successful the closer they got. Similarly, less cohesive shoaling may have also increased their vulnerability, as lingcod tended to stalk nonshoaling or straggling individuals. Concentration of predatory attacks upon lone fish or stragglers has been observed in both laboratory studies (Parrish 1989) and the field (Hobson 1968). Other more subtle aspects of juvenile walleye pollock behavior that were evident in trawl-stressed individuals, such as swimming at an upward angle or repeatedly poking their snouts out of the water, may have attracted the attention of lingcod, as predators often concentrate attacks upon individuals with disparate physical or behavioral characteristics (oddity effect: Hobson 1968, Landeau \& Terborgh 1986, Theodorakis 1989).

The extent of predation upon behaviorally impaired fish will also depend upon the local abundance of predators. Predators often aggregate around schooling prey (Hobson 1968, Pitcher 1980, Parrish 1992), and those predators not caught by the trawl may immediately capitalize upon injured and/or disoriented escapees. Bottom trawling activities may further concentrate predators and scavengers, which aggregate to feed upon exposed and injured benthic invertebrates (Kaiser \& Spencer 1994, 1996, Ramsay et al. 1996, 1998, Kaiser \& Ramsay 1997, Prena et al. 1999). Caddy (1973) documented winter flounder Pseudopleuronectes americanus densities 30 times higher inside, as opposed to outside dredge tracks within $1 \mathrm{~h}$ of dredge passage. Predators with acute olfactory ability, such as the sablefish Anoplopoma fimbria (Løkkeborg et al. 1995), can detect baits kilometers away and may be attracted to the olfactory plume generated by trawls, thereby exposing lingering escapees to elevated predation risk. Some predators follow trawlers. Perhaps most conspicuous are seabirds, which feed upon discards as well as small fish escaping the gear during haul-back and de-watering. However, the bottlenose dolphin Tursiops truncatus commonly follow Gulf of Mexico shrimp trawls, feeding upon juvenile fishes as they escape through the trawl meshes and bycatchreduction-devices (R. Overman, Georgia Sea Grant
Marine Extension Program, unpubl. video). Other cetaceans and pinnipeds are known to follow trawlers, but it is not known whether they predate escapees or simply feed upon discards and slippage (West 1983). Several species of predatory fish have been observed to follow Gulf of Mexico shrimp trawls, including the tuna Euthynmus alleteratus, the jack crevalle Caranx hippos and sharks, with the sharks occasionally biting the codend (Workman 1999). Clearly, whether as the result of learning, attraction to structure, or a simple optomotor response (Wardle 1983), any predator following a net would be well positioned to exploit behaviorally impaired escapees.

Numerous scientific studies have addressed the effect of mesh size, mesh geometry, and bycatchreduction-devices upon the size and species selectivity of trawls (Rogers et al. 1997, Brewer et al. 1998, Farmer et al. 1998, Perez-Comas et al. 1998, Tumilty et al. 1998, Halliday \& Cooper 1999). In many fisheries, such as the Bering Sea mid-water pollock fishery, larger mesh codends have been adopted by fishers, with the express goal of reducing the retention/bycatch of under-sized fish. This reflects a prevailing attitude among many fishers and managers that bycatch problems can be solved through mechanical separation in the trawl. However, reducing the numbers of undersized fishes which are landed does not provide proof that such measures are successful in significantly reducing mortality of these fishes. Studies of other fisheries demonstrate that there is bycatch associated with fishing activities that is unobserved from the boat, that is, fish escaping trawls die as a direct result of injuries suffered through interaction with the gear (Sangster et al. 1996, Suuronen et al. 1996a,b). The present study supports the existence of an unobserved bycatch which results indirectly from gear interaction: those fishes which survive trawl passage but are behaviorally impaired and succumb to predators in the subsequent hours and/or days. The results of this study cannot predict the magnitude of this mortality or the species that may be susceptible; that must await additional field research, perhaps incorporating commercial gear fitted with cages to retain codend escapees, as well as the development of in situ behavioral and/or biochemical assays to assess behavioral impairment. However, this work clearly demonstrates the need for a more thorough understanding of the interaction between fishes and fishing gears, with the goal of better quantifying and reducing the unobserved bycatch.

Acknowledgements. I wish to thank Michele Ottmar, Erik Sturm, Mara Spencer and Richard Titgen for their assistance with the laboratory experiments. Richard Titgen was also instrumental in the design of software enabling the analysis of predator-prey interactions from digitized files. I thank Bori 
Olla, Michael Davis and Al Stoner for their discussion of ideas which facilitated the design and execution of this study and (along with Steve Parker and David Eggelston) for critical comments on drafts of this manuscript. Cindy Sweitzer provided valuable assistance in preparing and proofing the manuscript.

\section{LITERATURE CITED}

Agardy T (2000) Effects of fisheries on marine ecosystems: a conservationist's perspective. ICES J Mar Sci 57:761-765

Alverson DL, Hughes SE (1996) Bycatch: from emotion to effective natural resource management. Rev Fish Biol Fish 6:443-462

Brewer D, Rawlinson N, Eayrs S, Burridge C (1998) An assessment of bycatch reduction devices in a tropical Australian prawn trawl fishery. Fish Res (Amst) 36:195-215

Broadhurst MK, Kennelly SJ, Barker DT (1997) Simulated escape of juvenile sand whiting (Sillago ciliata Cuvier) through square-meshes: effects on scale-loss and survival. Fish Res (Amst) 32:51-60

Brown JA, Johansen PH, Colgan PW, Mathers RA (1985) Changes in the predator avoidance behaviour of juvenile guppies (Poecilia reticulata) exposed to pentachlorophenol. Can J Zool 63:2001-2005

Caddy JF (1973) Underwater observations on tracks of dredges and trawls and some effects of dredging on a scallop ground. J Fish Res Board Can 30:173-180

Chopin FS, Arimoto T (1995) The condition of fish escaping from fishing gears - a review. Fish Res (Amst) 21:315-327

Clark PJ, Evans FC (1954) Distance to nearest neighbor as a measure of spatial relationships in populations. Ecology 35:445-453

Coutant CC (1973) Effect of thermal shock on vulnerability of juvenile salmonids to predation. J Fish Res Board Can 30: 965-973

Crowder LB, Murawski SA (1998) Fisheries bycatch: implications for management. Fisheries (Bethesda) 23:8-17

Day RW, Quinn GP (1989) Comparison of treatments after an analysis of variance in ecology. Ecol Monogr 59:433-463

Erickson D, Pikitich E, Suuronen P, Lehtonen E, Bublitz C, Klinkert C, Mitchell C (1999) Selective mortality of walleye pollock escaping from the codend and intermediate (= extension) section of a pelagic trawl. Final report. Saltstonstall-Kennedy Grant Program, Project No. NA36FD0149, Alaska Fisheries Development Foundation, Anchorage, AK

Farmer MJ, Brewer DT, Blaber SJM (1998) Damage to selected fish species escaping from prawn trawl codends: a comparison between square-mesh and diamond-mesh. Fish Res (Amst) 38:73-81

Fritz LW (1996) Juvenile walleye pollock, Theragra chalcogramma, bycatch in commercial groundfish fisheries in Alaskan waters. NOAA Tech Rep NMFS 126:179-195

Halliday RG, Cooper CG (1999) Evaluation of separator grates for reduction of bycatch in the silver hake (Merluccius bilinearis) otter trawl fishery off Nova Scotia, Canada. Fish Res (Amst) 40:237-249

Herting GE, Witt A Jr (1967) The role of physical fitness of forage fishes in relation to their vulnerability to predation by bowfin (Amia calva). Trans Am Fish Soc 96:427-430

Hicks C (1982) Fundamental concepts in the design of experiments. Holt Rinehart \& Winston, New York

Hobson ES (1968) Predatory behavior of some shore fishes in the Gulf of California. US Fish Widl Serv Res Rep 73:1-92

Kaiser MJ, Ramsay K (1997) Opportunistic feeding by dabs within areas of trawl disturbance: possible implications for increased survival. Mar Ecol Prog Ser 152:307-310

Kaiser MJ, Spencer BE (1994) Fish scavenging behaviour in recently trawled areas. Mar Ecol Prog Ser 112:41-49

Kaiser MJ, Spencer BE (1996) Behavioural responses of scavengers to beam trawl disturbance. In: Greenstreet SPR, Tasker ML (eds) Aquatic predators and their prey. Fishing News Books, Cambridge, p 116-123

Landeau L, Terborgh J (1986) Oddity and the 'confusion effect' in predation. Anim Behav 34:1372-1380

Lehtonen E, Tschernij V, Suuronen P (1998) An improved method for studying survival of fish that escape through meshes of trawl codends. Fish Res (Amst) 38:303-306

Little EE, Archeski RD, Flerov BA, Kozlovskaya VI (1990) Behavioral indicators of sublethal toxicity in rainbow trout. Arch Environ Contam Toxicol 19:380-385

Løkkeborg S, Olla BL, Pearson WH, Davis MW (1995) Behavioural responses of sablefish, Anoplopoma fimbria, to bait odour. J Fish Biol 46:142-155

McKelvey DR (1996) Juvenile walleye pollock, Theragra chalcogramma, distribution and abundance in Shelikof Strait-what can we learn from acoustic survey results? NOAA Tech Rep NMFS 126: p 25-34

Mesa MG (1994) Effects of multiple acute stressors on the predator avoidance ability and physiology of juvenile chinook salmon. Trans Am Fish Soc 123:786-793

Mesa MG, Poe TP, Gadomski DM, Petersen JH (1994) Are all prey created equal? A review and synthesis of differential predation on prey in substandard condition. J Fish Biol 45 (Suppl A):81-96

Mesa MG, Poe TP, Maule AG, Schreck CB (1998) Vulnerability to predation and physiological stress responses in juvenile chinook salmon (Oncorhynchus tshawytscha) experimentally infected with Renibacterium salmoninarum. Can J Fish Aquat Sci 55:1599-1606

Olla BL, Davis MW (1989) The role of learning and stress in predator avoidance of hatchery-reared coho salmon (Oncorhynchus kitsutch), juveniles. Aquaculture 76: 209-214

Olla BL, Davis MW (1992) Comparison of predator avoidance capabilities with corticosteroid levels induced by stress in juvenile coho salmon. Trans Am Fish Soc 121:544-547

Olla BL, Davis MW, Schreck CB (1995) Stress-induced impairment of predator evasion and non-predator mortality in Pacific salmon. Aquacult Res 26:393-398

Olla BL, Davis MW, Schreck CB (1997) Effects of simulated trawling on sablefish and walleye pollock: the role of light intensity, net velocity and towing duration. J Fish Biol 50: 1181-1194

Olla BL, Davis MW, Rose C (2000) Differences in orientation and swimming of walleye pollock Theragra chalcogramma in a trawl net under light and dark conditions: concordance between field and laboratory observations. Fish Res (Amst) 44:261-266

Parrish JK (1989) Re-examining the selfish herd: are central fish safer? Anim Behav 38:1048-1053

Parrish JK (1992) Levels of diurnal predation on a school of flat-iron herring, Harengula thrissina. Environ Biol Fish 34:257-263

Perez-Comas JA, Erickson DL, Pikitch EK (1998) Cod-end mesh size selection for rockfish and flatfish of the US west coast. Fish Res (Amst) 34:247-268

Pitcher TJ (1980) Some ecological consequences of fish school volumes. Freshw Biol 10:539-544

Prena J, Schwinghamer P, Rowell TW, Gordon DC Jr, Gilkinson KD, Vass WP, McKeown DL (1999) Experimental otter trawling on a sandy bottom ecosystem of the Grand Banks 
of Newfoundland: analysis of trawl bycatch and effects on epifauna. Mar Ecol Prog Ser 181:107-124

Ramsay K, Kaiser MJ, Hughes RN (1996) Changes in hermit crab feeding patterns in response to trawling disturbance. Mar Ecol Prog Ser 144:63-72

Ramsay K, Kaiser MJ, Hughes RN (1998) Responses of benthic scavengers to fishing disturbance by towed gears in different habitats. J Exp Mar Biol Ecol 224:73-89

Rice JA, Crowder LB, Binkowski FP (1987) Evaluating potential sources of mortality for larval bloater (Coregonus hoyi): starvation and vulnerability to predation. Can J Fish Aquat Sci 44:467-472

Rogers DR, Rogers BD, de Silva JA, Wright VL, Watson JW (1997) Evaluation of shrimp trawls equipped with bycatch reduction devices in inshore waters of Louisiana. Fish Res (Amst) 33:55-72

Sangster GI, Lehmann K, Breen M (1996) Commercial fishing experiments to assess the survival of haddock and whiting after escape from four sizes of diamond mesh cod-ends. Fish Res (Amst) 25:323-345

Schreck CB, Olla BL, Davis MW (1997) Behavioral responses to stress. In: Iwama GK, Pickering AD, Sumpter JP, Schreck CB (eds) Fish stress and health in aquaculture. Cambridge University Press, New York, p 145-170

Sokal RR, Rohlf FJ (1969) Biometry. The principles and practice of statistics in biological research. WH Freeman \& Co, San Francisco

Suuronen P, Turunen T, Kiviniemi M, Karjalainen J (1995) Survival of vendace (Coregonus albula) escaping from a trawl cod end. Can J Fish Aquat Sci 52:2527-2533

Suuronen P, Lehtonen E, Tschernij V, Larsson PO (1996a) Skin injury and mortality of Baltic cod escaping from trawl codends equipped with exit windows. Arch Fish Mar Res 44:165-178

Suuronen P, Erickson DL, Orrensalo A (1996b) Mortality of herring escaping from pelagic trawl codends. Fish Res (Amst) 25:305-321

Suuronen P, Lehtonen E, Wallace J (1997a) Avoidance and escape behaviour by herring encountering midwater trawls. Fish Res (Amst) 29:13-24

Editorial responsibility: Otto Kinne (Editor), Oldendorf/Luhe, Germany
Suuronen P, Erickson D, Pikitch E (1997b) Mesh-size management in pelagic trawl fisheries-potential solutions. In: Hancock DA, Smith DC, Grant A, Beumer JP (eds) Developing and sustaining world fisheries resources: the state of science and management. CSIRO Publishing, Collingwood, p 563-567

Theodorakis CW (1989) Size segregation and the effects of oddity on predation risk in minnow schools. Anim Behav 38:496-502

Thiele W, Kroeger M, Gau S, Hopp M, Klüber U (1997) Flow measurements in a codend. Int Counc Explor Sea Comm 1997/FF:10:1-9

Tumilty JE, McCormick R, van Marlen B, Fonteyne R, Lange K (1998) Towed fishing gear reducing discards by consideration of all factors affecting selectivity. In: Barthel KG, Barth H, Bohle-Carbonell M, Fragakis C, Lipiatou E, Martin P, Ollier G, Weydert M (eds) Third European Marine Science and Technology Conference (MAST Conference), European Commission DG 12 Science, Research and Development, Luxembourg, p 204-206

Turunen T, Suuronen P, Hyvaerinen H, Rouvinen J (1996) Physiological status of vendace (Coregonus albula L) escaping from a trawl codend. Nord J Freshw Res 72: $39-44$

Wardle CS (1983) Fish reactions to towed fishing gears. In: MacDonald A, Priede IG (eds) Marine biology at sea. Academic Press, New York, p 167-195

Webb PW, Zhang H (1994) The relationship between responsiveness and elusiveness of heat- shocked goldfish (Carassius auratus) to attacks by rainbow trout (Oncorhynchus mykiss). Can J Zool 72:423-426

West CW (1983) Observations of trawl-sea lion interactions in the 1983 Shelikof Strait Joint Venture Walleye Pollock Fishery. Report 83-16, Northwest and Alaska Fisheries Center, Seattle

Workman IK (1999) Fate of juvenile red snapper, Lutjanus campechanus, that escape from shrimp trawls. In: Red Snapper/Shrimp Research Program Summer 1998 Project. Final Report. Southeast Fisheries Science Center, Galveston, TX

Submitted: April 4, 2001; Accepted: October 16, 2001 Proofs received from author(s): April 9, 2002 